Kocaeli Üniversitesi Sağlık Bilimleri Dergisi

\title{
HYPERFIBRINOLYSIS; A SERIOUS and MORTAL COMPLICATION AFTER CARDIOPULMONARY BYPASSES: CASE REPORT
}

\section{HIPERFIBRINOLIZIS; KARDIOPULMONER BYPASS SONRASI GELIŞEN CIDDİ ve MORTAL BİR KOMPLIKASYON: OLGU SUNUMU}

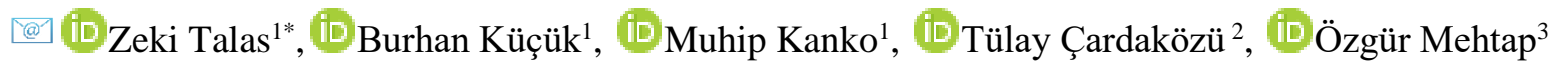

\author{
${ }^{1}$ Kocaeli University School of Medicine, Department of Cardiovascular Surgery, ${ }^{2}$ Department of Anesthesia and Reanimation, ${ }^{3}$ Department of \\ Hematology, Kocaeli, Turkey
}

ORCID iD: Zeki Talas: 0000-0001-6465-6170; Burhan Küçük: 0000-0002-6544-5639; Muhip Kanko: 0000-0003-4339-2019; Tülay Çardaközü: 00000002-4936-8020; Özgür Mehtap: 0000-0002-5603-1178

\begin{tabular}{lrr}
\hline *Sorumlu Yazar / Corresponding Author: Zeki Talas, e-posta / e-mail: zekitalas @ gmail.com & \\
\hline Geliş Tarihi / Received: 30.11 .2020 & Kabul Tarihi / Accepted: 19.08.2021 & Yayım Tarihi / Published: 31.10 .2021 \\
\hline
\end{tabular}

\begin{abstract}
Hemorrhage is one of the major complications of cardiac surgery when using cardiopulmonary bypass (CPB). Despite all kinds of medical and surgical treatment, post bypass bleeding is still a serious problem. Hypothermia, acidosis, hypovolemia, and hypoperfusion lead to disruption of the coagulation process in severe trauma as well as in CPB. Hyperfibrinolysis (HF) is a life-threatening bleeding disorder in major trauma patients. The incidence of $\mathrm{HF}$ has been estimated in the range of $15 \%$ to $20 \%$. The gold standard for the detection of HF is thrombelastography or thromboelastometry. Blood products and tranexamic acid are used in the treatment of hyperfibrinolysis. The agents that can be used as an alternative to tranexamic acid in $\mathrm{HF}$ treatment are aprotinin and epsilon aminocaproic acid.

Early diagnosis and treatment of HF are life-saving. For this purpose, we wanted to share this rare pathology.
\end{abstract}

Keywords: Hyperfibrinolysis, cardiopulmonary bypass, hemorrhage.

\section{$\ddot{\mathbf{O z}}$}

Kanama, kardiyopulmoner bypass (CPB) kullanılarak yapılan kalp cerrahisinin en önemli komplikasyonlarından biridir. Her türlü tıbbi ve cerrahi tedaviye rağmen baypas sonrası kanama hala ciddi bir problemdir. Ağır travmada olduğu gibi hipotermi, asidoz, hipovolemi, hipoperfüzyon nedeni ile CPB da pıhtılaşma sürecinin bozulmasına neden olur. Majör travma ve majör cerrahi sonrasında gelişebilen Hiperfibrinoliz (HF), yaşamı tehdit eden ciddi kanama bozukluğuna sebep olabilir. Kalp cerrahisi sonrası HF görülme sıklığ $\% 15$ ile \% 20 arasında tahmin edilmektedir. HF tanısında altın standart trombelastografi veya trombelastometridir. Hiperfibrinoliz tedavisinde kan ürünleri ve traneksemik asit kullanılır. HFtedavisinde traneksemik aside alternatif olarak kullanılabilen ajanlar aprotinin ve epsilon aminokaproik asittir. Kalp cerrahisi sonrası gelişen kanama problemlerinde HF tanısı gözden kaçabilir. Bu nedenle erken teşhis ve tedavinin hayat kurtarıcı olduğu bu nadirpatolojiyi paylaşmak istedik.

Anahtar Kelimeler: Hiperfibrinoliz, kordiopulmoner bypas, kanama. 


\section{Introduction}

Hemorrhage is one of the significant complications of cardiac surgery when using cardiopulmonary bypass (CPB). Despite all kinds of medical and surgical treatment, post bypass bleeding is still a severe problem. ${ }^{1}$ Hypothermia, acidosis, hypovolemia, and hypoperfusion disrupt the coagulation process in severe trauma, and CPB. ${ }^{2}$ Hyperfibrinolysis (HF) is a life-threatening bleeding disorder in major trauma patients. ${ }^{3}$ The incidence of HF has been estimated in the range of $15 \%$ to $20 \% .^{4}$ The gold standard for the detection of $\mathrm{HF}$ is thrombelastography or thromboelastometry. ${ }^{5-6}$ Blood products and tranexamic acid are used in the treatment of hyperfibrinolysis. The agents that can be used as an alternative to tranexamic acid in HF treatment are aprotinin and epsilon aminocaproic acid (EACA). ${ }^{7}$ Early diagnosis and treatment are life-saving. ${ }^{1}$ For this purpose, we wanted to share this rare pathology.

\section{Case Report}

A 67-year-old male patient was hospitalized for heart valve surgery due to advanced aortic insufficiency and stenosis with progressive mitral regurgitation. The routine blood tests and coagulation tests performed during the preoperative preparation period were regular (Table1).

Table 1. Preoperative hemogram and coagulation tests

\begin{tabular}{lccc}
\hline \multicolumn{1}{c}{ Parameters } & Value & Unit & Reference range \\
\hline Hgb & 16.1 & $\mathrm{~g} / \mathrm{dL}$ & $12.5-16.3$ \\
Htc & 47.4 & $\%$ & $36.7-47.1$ \\
PLT & 206 & $\mathrm{X} 10^{3} / \mathrm{mL}$ & $152-348$ \\
PTT & 15.3 & $\mathrm{sec}$ & $11.5-15.5$ \\
PTT (activation) & 83 & $\%$ & $70-100$ \\
APTT & 31.7 & & \\
INR & 1.13 & $\mathrm{sec}$ & $26.5-40$ \\
\hline
\end{tabular}

Hgb: Hemoglobin, Htc: Hematocrit, PLT: Platelet, PTT: Prothrombin Time, APTT: Activated Partial Thromboplastin Time, INR: International normalized ratio

Aortic valve replacement (AVR) and mitral valve replacement (MVR) operation was performed using routine median sternotomy and $\mathrm{CPB}$ with prosthetic valves. After the procedure, the patient was followed up in the cardiovascular surgery intensive care unit (ICU). During the ICU follow-up, there was approximately 150-200 cc of hemorrhagic drainage per hour from the thorax and mediastinal drains. Therefore, the patient was treated with a total of 2 IU of erythrocyte suspension, 1IU of fresh frozen plasma, and $1 \mathrm{IU}$ of platelet suspension. Protamine treatment was started when the Activated Clotting Time (ACT) was $166 \mathrm{sec}$, and $500 \mathrm{mg}$ of tranexamic acid was added. At the end of the 6-hours followup, the patient was re-operated for bleeding revision; the total drainage was $1100 \mathrm{cc}$ despite replacement and treatment. It was observed that there was no active surgical bleeding focus in the revision operation. Upon this, the patient was adequately closed and taken to the ICU stably under fourinotropic therapy. On the first night of postop, the patient underwent a total of 2 IU ES(erythrocyte suspension), 2 IU FFP (fresh frozen plasma), and 1 IU PS (platelet suspension ) replacement.

The drainage amount was measured as $850 \mathrm{~mL}$ (approximately 12 hours) until the morning of the postoperative first day after revision. Since there was no active surgical bleeding, we decided to consult with the hematology clinic. The examinations required as a result of the consultation are as follows. The D-dimer test result was typical (Table 2).

Table 2. Postoperative first day morning test results

\begin{tabular}{lccc}
\hline \multicolumn{1}{c}{ Parameters } & Value & Unit & Reference range \\
\hline PTT & 26.6 & $\mathrm{sec}$ & $11.5-15.5$ \\
PTT (activation) & 40 & $\%$ & $70-100$ \\
APTT & 37.8 & & \\
INR & 2.01 & $\mathrm{sec}$ & $26.5-40$ \\
Fibrinogen & 1.38 & $\mathrm{~g} / \mathrm{dL}$ & $2-4$ \\
\hline
\end{tabular}

PTT: Prothrombin Time, APTT: Activated Partial Thromboplastin Time, INR: international normalized ratio, Fibrinogen: Fibrinogen

Upon this, the patient was considered to have hyperfibrinolysis (HF) with the hematology department. A total of 3IU ES, 3IU FFP, and 1IU PS replacement were applied to the patient with $1000 \mathrm{mg}$ of tranexamic acid treatment. Along with a 2-gram Fibrinogen, the supplement was made. Under these treatments, the patient was extubated. The 24-hour drainage amount was measured as $1300 \mathrm{~mL}$ on the first postoperative day. Fibrinogen tests returned to normal in the control tests performed after treatment (Table3).

Table 3. Postoperative first day evening fibrinogen and D-dimer levels

\begin{tabular}{lccc}
\hline Parameters & Value & Unit & Reference range \\
\hline Fibrinogen & 2.08 & $\mathrm{~g} / \mathrm{L}$ & $2-4$ \\
D-Dimer & 0.47 & $\mathrm{mg} / \mathrm{mL}$ & $0-0.5$ \\
\hline
\end{tabular}

There was no problem other than a decrease in hemogram level, low platelet values, and PT elevation in coagulation tests on the second postoperative day (Table 4).

Table 4. Postoperative second-day results

\begin{tabular}{lccc}
\hline Parameters & Value & Unit & Reference range \\
\hline Hgb & 8.0 & $\mathrm{~g} / \mathrm{dL}$ & $12.5-16.3$ \\
Htc & 24.7 & $\%$ & $36.7-47.1$ \\
PLT & 94 & $\mathrm{X} 10^{3} / \mathrm{mL}$ & $152-348$ \\
PTT & 19.6 & $\mathrm{sec}$ & $11.5-15.5$ \\
PTT (activation) & 59 & $\%$ & $70-100$ \\
APTT & 32.2 & & \\
INR & 1.46 & $\mathrm{sec}$ & $26.5-40$ \\
Fibrinogen & 3.64 & $\mathrm{~g} / \mathrm{L}$ & $2-4$ \\
D-Dimer & 0.49 & $\mathrm{mg} / \mathrm{mL}$ & $0-0.5$ \\
\hline
\end{tabular}

Hgb: Hemoglobin, Htc: Hematocrit, PTT: Prothrombin Time, APTT: Activated Partial Thromboplastin Time, INR: international normalized ratio

On the second postoperative day, the patient's treatment was planned as 1IU ES and 2IU FFP replacements and Tranexamic acid $500 \mathrm{mg}$ treatment. Fibrinogen therapy was not performed, as the fibrinogen levels returned to normal. As the patient did not need it during the day, all inotropic 
supportive treatments except Dopamine were gradually decreased and discontinued. On the second postoperative day, the total amount of drainage fell to $800 \mathrm{~mL}$.

On the third postoperative day, we used only 2IU ES replacement in the treatment of the patient. No additional treatment was required.24-hour drainage of the patient decreased to $300 \mathrm{~mL}$. The patient was taken to the cardiovascular surgery service on the 4th postoperative day and was discharged without any problem on the 10th postoperative day.

\section{Discussion}

Hemorrhage is one of the major complications after cardiac surgery with cardiopulmonary bypass (CPB). Despite all kinds of medical and surgical treatment, postoperative bleeding after cardiac surgery is still severe. Hyperfibrinolysis (HF) can be one of the reasons for nonsurgical bleeding after $\mathrm{CPB} .^{1}$ Hyperfibrinolysis is a pathology with uncontrolled increased fibrinolytic activity to fibrin formation and is associated with excessive bleeding. ${ }^{7}$ The incidence of HF has been estimated at $15 \%$ to $20 \% .^{4}$

Scanned our last five years of data, although there were operations with CPB in our clinic for many years, HF-related bleeding was not observed. Therefore, we wanted to share this rare complication.

The gold standard for diagnosing HF is thrombelastography or thrombelastometry. ${ }^{5}$ Levrat et al. expilained that thromboelastography remains a complex and timeconsuming procedure. For the same reasons, the other techniques used to diagnose hyperfibrinolysis (plasminantiplasmin complex, plasminogen activator inhibitor-1, thrombin activatable fibrinolytic inhibitor, Ddimers/plasmin-antiplasmin) are also not relevant in the context of hemorrhagic shock. Furthermore, we cannot do these tests routinely for logistic and economic reasons. ${ }^{8}$ Since there is no possibility of thromboelastography in our clinic, we used routine blood tests and coagulation tests while diagnosing the patient's HF. Disseminated intravascular coagulation (DIC) is an important problem in the differential diagnosis. While DIC has schistocytes in the peripheral smear, platelet counts are low. Prothrombin time(PTT) and activated partial thromboplastin time(APTT) are prolonged, and D-dimer levels are above average. Fibrinogen values are typical. ${ }^{9}$

Due to the absence of schistocytes in the peripheral smear of the patient, standard D-Dimer test, low fibrinogen values, and prolonged PTT, HF was considered for diagnosis. The only condition that did not comply with HF was a decrease in the patient's platelet levels. However, because thrombocytopenia was not profound and progressive, DIC was not considered. Thrombocytopenia was thought to be due to excessive bleeding.

Blood products (such as ES, FFP, PS) and tranexamic acid are used to treat hyperfibrinolysis. The agents that can be used as an alternative to tranexamic acid in HF treatment are aprotinin and epsilon aminocaproic acid. ${ }^{7}$ Patients who received empiric dosing of tranexamic acid (TXA) had lower overall mortality and a lower risk of death due to bleeding in The Clinical Randomization of an Antifibrinolytic in Significant Haemorrhage (CRASH)-2 trial. ${ }^{10}$ It is used routinely in elective cardiac surgery or some severe surgeries. It has been shown to reduce blood loss and the need for blood transfusion without increased thromboembolic events and is easily accessible and helpful. ${ }^{11}$ TXA was administered as a 1 $\mathrm{g}$ bolus over 10 minutes followed by a second $1 \mathrm{~g}$ infusion over eight hours. ${ }^{7}$ Compared with TXA, the synthetic lysine analog EACA(epsilon aminocaproic acid) is ten times less potent and is not associated with reduced transfusion requirements in elective surgery. Aprotinin was withdrawn from the market after it was associated with increased mortality in a randomized trial of patients undergoing cardiac surgery. ${ }^{12}$

For our patient, we used a total of 10 IU ES, 8 IU FFP, 3 IU PS replacements after the operation day when HF developed as a blood product with the replacement, and Tranexamic acid treatment was started as $2 \mathrm{~g}$ per day. Since the fibrinogen level was low on the first postoperative day, we added $2 \mathrm{~g}$ of fibrinogen therapy. We continued the tranexamic acid treatment until the third day after the operation. On the third postoperative day, the amount of drainage dropped to normal levels, and the drainage turned normal. The patient was discontinued on the 4th day by stopping tranexamic acid treatment and was discharged on the 10th day without any problem.

\section{Conclusion}

HF is a significant problem that can cause cardiac surgery, severe mortal bleeding. It should be considered in bleeding that started in the early period after cardiac surgery, and the cause of which cannot be explained. The diagnosis is supported by the absence of schistocytes in the peripheral smear, normal D-dimer levels, and average platelet counts, with prolonged PTT and APTT in patients with bleeding in the early period after cardiopulmonary bypass. Early diagnosis and treatment are life-saving. For this purpose, we wanted to share this rare pathology.

\section{Author Contributions}

ZT, MK: Design; MK: Project development; ZT, BK: Data collection; ZT: Analysis; ZT: Literature search; ZT, TÇ, ÖM: Manuscript writing; ZT, MK: Critical review

\section{References}

1. Kuepper F, Dangas G, Mueller-Chorus A, Kulka PM, Zenz M, Wiebalck A. Fibrinolytic Activity and Bleeding After Cardiac Surgery With Cardiopulmonary Bypass and Low-Dose Aprotinin Therapy. Clinical Trial Blood Coagul Fibrinolysis. 2003 Feb;14(2):147-53. doi: 10.1097/00001721-20030200000005.

2. Schöchl H, Thomas F, Michaela P, Csilla J. Hyperfibrinolysis After Major Trauma: Differential Diagnosis of Lysis Patterns and Prognostic Value of Thrombelastometry. The Journal of Trauma: Injury, Infection, and Critical Care: July 2009 Volume 67 - Issue 1 - $\mathrm{p}$ 125-131 doi: 10.1097/TA.0b013e31818b2483

3. Schöchl H, Voelckel W, Maegele M, Solomon C. Traumaassociated Hyperfibrinolysis. Hamostaseologie. 2012;32(1):22-7. doi: 10.5482/ha-1178

4. Kapsch DN, Metzler M, Harrington M, Mitchell FL, Silver D. Fibrino-lytic response to trauma. Surgery. 1984;95:473- 478

5. Luddington RJ. Thromboelastography/thromboelastometry. Clin Lab Haematol. 2005;27:81-90

6. Spiel AO, Mayr FB, Firbas C, Quehenberger P, Jilma B. Validation of rotation thrombelastography in a model of systemic activation of fibrinoly-sis and coagulation in humans. J Thromb Haemost. 2006;4:411-416

7. Lewis S. Gall, Karim Brohi, Ross A. Davenport. Diagnosis and Treatment of Hyperfibrinolysis in Trauma (A European Perspective). Semin Thromb Hemost 2017; 43(2): 224-234. DOI: $10.1055 / \mathrm{s}-0036-1598001$

8. Levrat A., Gros A., Rugeri L., Inaba K., Floccard B., Negrier C., David JS et al. Evaluation of rotation thrombelastography for the diagnosis of hyperfibrinolysis in trauma patients. BJA: 
British Journal of Anaesthesia, Volume 100, Issue 6, June 2008, Pages 792-797, https://doi.org/10.1093/bja/aen083

9. Türk hematoloji derneği - temel hemostaz tromboz kursu. https://www.thd.org.tr/thdData/userfiles/file/2007thtk_03.pdf. Koagülasyon testleri ve klinik kullanımı. 8 Eylül 2007 erişildi.

10. 1Shakur H, Roberts I, Bautista R, et al; CRASH-2 trial collaborators. Effects of tranexamic acid on death, vascular occlusive events, and blood transfusion in trauma patients with significant haemorrhage (CRASH-2): a randomised, placebocontrolled trial. Lancet 2010; 376 (9734): 23-32

11. Ker K, Edwards P, Perel P, Shakur H, Roberts I. Effect of tranexamic acid on surgical bleeding: systematic review and cumulative meta-analysis. Br Med J 2012; 344: e3054

12. Fergusson DA, Hébert PC, Mazer CD, et al; BART Investigators. A comparison of aprotinin and lysine analogues in high-risk cardiac surgery. $N$ Engl J Med 2008; 358 (22) 2319-2331 